University of Nebraska - Lincoln

DigitalCommons@University of Nebraska - Lincoln

The acute toxicity of the death camas (Zigadenus species) alkaloid zygacine in mice, including the effect of the methyllycaconitine coadministration on zygacine toxicity

\author{
K. D. Welch \\ USDA-ARS, kevin.welch@ars.usda.gov \\ K. E. Panter \\ USDA-ARS \\ D. R. Gardner \\ USDA-ARS
}

B. L. Stegelmeier

USDA-ARS

B. T. Green

USDA-ARS

See next page for additional authors

Follow this and additional works at: https://digitalcommons.unl.edu/usdaarsfacpub

Part of the Agricultural Science Commons

Welch, K. D.; Panter, K. E.; Gardner, D. R.; Stegelmeier, B. L.; Green, B. T.; Pfister, J. A.; and Cook, D., "The acute toxicity of the death camas (Zigadenus species) alkaloid zygacine in mice, including the effect of the methyllycaconitine coadministration on zygacine toxicity" (2011). Publications from USDA-ARS / UNL Faculty. 797.

https://digitalcommons.unl.edu/usdaarsfacpub/797

This Article is brought to you for free and open access by the U.S. Department of Agriculture: Agricultural Research Service, Lincoln, Nebraska at DigitalCommons@University of Nebraska - Lincoln. It has been accepted for inclusion in Publications from USDA-ARS / UNL Faculty by an authorized administrator of DigitalCommons@University of Nebraska - Lincoln. 


\section{Authors}

K. D. Welch, K. E. Panter, D. R. Gardner, B. L. Stegelmeier, B. T. Green, J. A. Pfister, and D. Cook 


\section{JOURNAL OF ANIMAL SCIENCE}

The Premier Journal and Leading Source of New Knowledge and Perspective in Animal Science

The acute toxicity of the death camas (Zigadenus species) alkaloid zygacine in mice, including the effect of methyllycaconitine coadministration on zygacine toxicity

K. D. Welch, K. E. Panter, D. R. Gardner, B. L. Stegelmeier, B. T. Green, J. A. Pfister and D. Cook

J Anim Sci 2011. 89:1650-1657.

doi: $10.2527 /$ jas.2010-3444

The online version of this article, along with updated information and services, is located on the World Wide Web at:

http://jas.fass.org/cgi/content/full/89/5/1650 


\title{
The acute toxicity of the death camas (Zigadenus species) alkaloid zygacine in mice, including the effect of methyllycaconitine coadministration on zygacine toxicity ${ }^{1}$
}

\author{
K. D. Welch, ${ }^{2}$ K. E. Panter, D. R. Gardner, B. L. Stegelmeier, B. T. Green, \\ J. A. Pfister, and D. Cook
}

USDA-ARS Poisonous Plant Research Laboratory, Logan, UT 84341

\begin{abstract}
Death camas (Zigadenus spp.) is a common poisonous plant on foothill rangelands in western North America. The steroidal alkaloid zygacine is believed to be the primary toxic component in death camas. Poisonings on rangelands generally occur in the spring when death camas is abundant, whereas other more desirable forage species are limited in availability. In most cases where livestock are poisoned by plants in a range setting, there is more than one potential poisonous plant in that area. One common poisonous plant that is often found growing simultaneously in the same area as death camas is low larkspur (Delphinium nuttallianum). Consequently, the objectives of this study were to conduct acute toxicity studies in mice and to determine if coadministration of low larkspur will exacerbate the toxicity of death camas. We first characterized the acute toxicity of zygacine in mice. The $\mathrm{LD}_{50}$ of zygacine administered intravenously (i.v.) and orally was $2.0 \pm$ 0.2 and $132 \pm 21 \mathrm{mg} / \mathrm{kg}$, respectively. The rate of elimination of zygacine from whole blood was determined to
\end{abstract}

be $0.06 \pm 0.01 / \mathrm{min}$, which corresponds to an elimination half-life of $13.0 \pm 2.7 \mathrm{~min}$. The i.v. $\mathrm{LD}_{50}$ of total alkaloid extracts from a Utah and a Nevada collection were $2.8 \pm 0.8$ and $2.2 \pm 0.3 \mathrm{mg} / \mathrm{kg}$, respectively. The i.v. $\mathrm{LD}_{50}$ of methyllycaconitine (MLA), a major toxic alkaloid in low larkspur, was $4.6 \pm 0.5 \mathrm{mg} / \mathrm{kg}$, whereas the i.v. $\mathrm{LD}_{50}$ of a 1:1 mixture of MLA and zygacine was $2.9 \pm 0.7 \mathrm{mg} / \mathrm{kg}$. The clinical signs in mice treated with this mixture were very similar to those of mice treated with zygacine alone, including the time of onset and death. These results suggest that there is an additive effect of coadministering these 2 alkaloids i.v. in mice. The results from this study increase knowledge and understanding regarding the acute toxicity of death camas. As combined intoxications are most likely common, this information will be useful in further developing management recommendations for ranchers and in designing additional experiments to study the toxicity of death camas to livestock.

Key words: death camas, lethal dose 50\%, methyllycaconitine, mouse, Zigadenus, zygacine

(C)2011 American Society of Animal Science. All rights reserved.

J. Anim. Sci. 2011. 89:1650-1657 doi:10.2527/jas.2010-3444

\section{INTRODUCTION}

There are many species of death camas (Zigadenus spp.) located in North America (Burrows and Tyrl, 2001; Knight and Walter, 2001). Death camas is one of the first species to grow in the spring. Poisonings generally occur during the spring when death camas is abundant, while other forage species have little growth. Poisonings also occur on overgrazed ranges where better quality forage has been depleted, or when management errors result in hungry animals being moved into death

\footnotetext{
${ }^{1}$ The authors thank Kendra Dewey, Ed Knoppel, and Scott Larsen (all from the USDA-ARS Poisonous Plant Research Laboratory, Logan, UT) for their expert technical support.

${ }^{2}$ Corresponding author: Kevin.Welch@ars.usda.gov

Received August 19, 2010.

Accepted December 14, 2010.
}

camas-infested areas (Panter et al., 1987). Livestock losses to death camas have been reported in numerous species including cattle (Smith and Lewis, 1991; Collet et al., 1996), horses (Morris, 1944), and sheep (Panter et al., 1987), with the largest losses generally occurring in sheep (Kingsbury, 1964). Sheep are primarily affected because of their tendency to select forbs, particularly in the early spring when there is little other plant growth. Clinical signs of poisoning are similar for all animal species studied (Panter et al., 2007). Zygacine (Figure 1 ) is often the most abundant alkaloid in death camas and is consequently believed to be the primary toxic component (Gilbertson, 1973; Majak et al., 1992).

In most cases in which livestock are poisoned by plants in a range setting, there are multiple poisonous plants in the area where the animals were poisoned. A common poisonous plant found growing simultaneously 


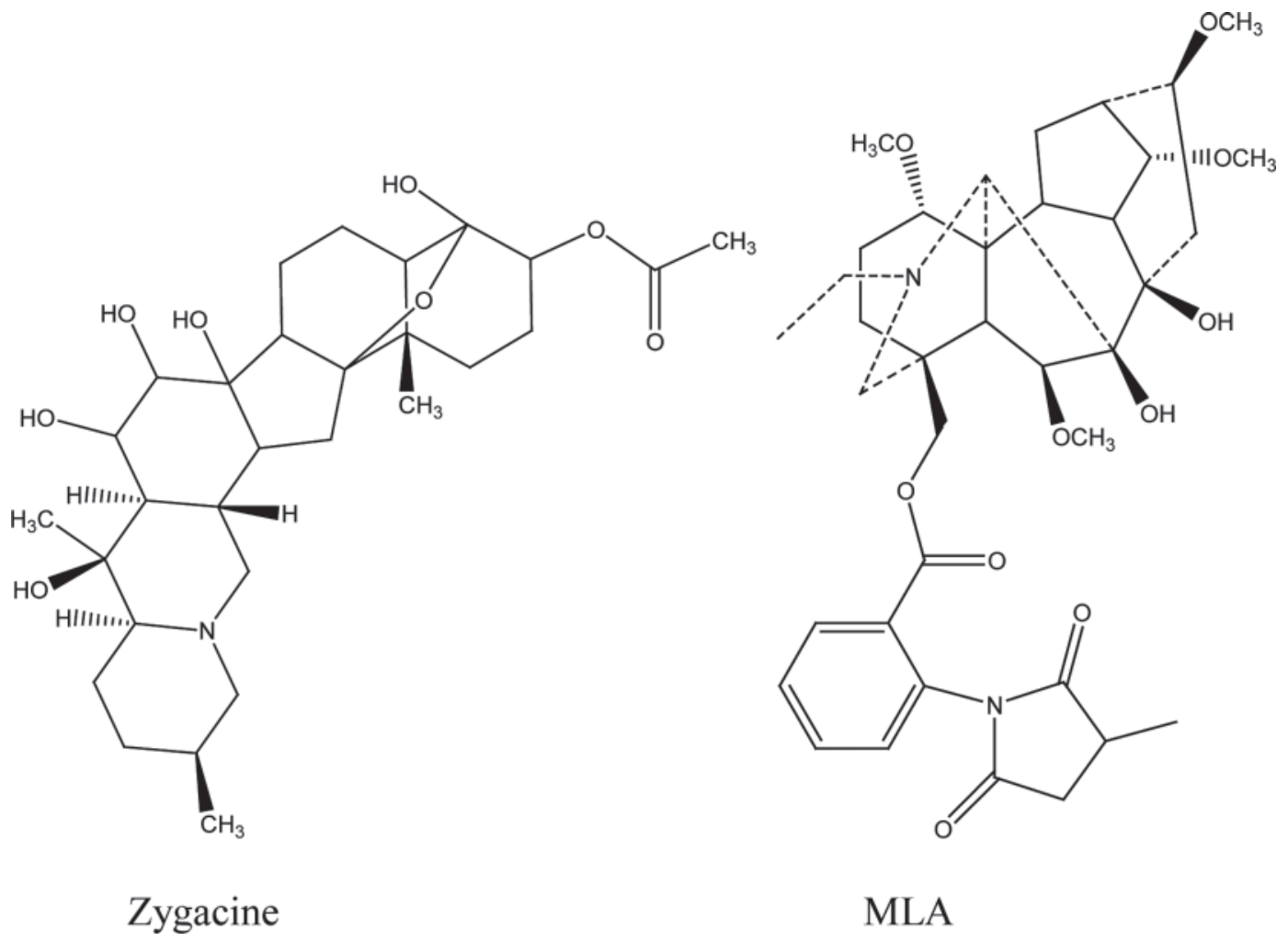

Figure 1. Chemical structure of zygacine, the main alkaloid in Zigadenus paniculatus, and methyllycaconitine (MLA), a major toxic alkaloid in low larkspur.

in the same area as death camas is low larkspur (Delphinium nuttallianum). Consequently, the objectives of this study were to conduct preliminary acute toxicity studies in mice and to determine if the coadministration of methyllycaconitine (MLA; Figure 1), one of the major toxic alkaloids from low larkspur, exacerbates the toxicity of zygacine. To accomplish this objective, we characterized several different variables describing the acute toxicity of zygacine in mice.

\section{MATERIALS AND METHODS}

All procedures were conducted under veterinary supervision and were approved by the Utah State University Institutional Animal Care and Use Committee.

\section{Alkaloid Preparation}

Zygacine and death camas total alkaloid extracts were extracted from Zigadenus paniculatus that was collected in the late pod stage near Logan, Utah $\left(41^{\circ} 46.098^{\prime}\right.$ $\mathrm{N}, 111^{\circ} 46.688^{\prime} \mathrm{W}$, elevation $1,539 \mathrm{~m}$ ). A crude alkaloid extract was also isolated from $Z$. paniculatus that was collected in the late pod stage near Tuscarora, Nevada $\left(41^{\circ} 38.167^{\prime} \mathrm{N}, 116^{\circ} 21.947^{\prime} \mathrm{W}\right.$, elevation $\left.1,586 \mathrm{~m}\right)$. Crude alkaloids were isolated from dry ground plant material $(50 \mathrm{~g})$ by extraction with $1 \mathrm{~L}$ of methanol for $24 \mathrm{~h}$. The mixture was filtered and the methanol extract was concentrated by removal of the methanol using rotary evaporation under reduced pressure at $45^{\circ} \mathrm{C}$. The residue was then rinsed multiple times with $25 \mathrm{~mL}$ of $1 \%$ sulfuric acid and $25 \mathrm{~mL}$ of chloroform for a total volume of $250 \mathrm{~mL}$, which was placed into a separatory funnel. The chloroform portion was drained and the acid solution was extracted 2 additional times with $100 \mathrm{~mL}$ of chloroform. The acid solution was cooled in an ice bath and the $\mathrm{pH}$ was adjusted to $\approx 10$ by the slow addition of $28 \%$ ammonium hydroxide. The aqueous base solution was then placed into a separatory funnel and extracted 3 times with $100 \mathrm{~mL}$ of chloroform. Chloroform extracts were combined and dried over anhydrous sodium sulfate, filtered, and the solvent removed under reduced pressure by rotary evaporation. The dried crude alkaloid residue was scraped from the round bottom flask, weighed, and stored at $-20^{\circ} \mathrm{C}$. Zygacine was isolated and purified from the crude alkaloid residue by flash chromatography on silica gel $(5 \times 11$ cm column) eluting with $2 \%$-increase step gradients of chloroform/methanol/ammonium hydroxide (98/2/0.1 to $90 / 10 / 0.1$ ) and then crystallization from hexane/acetone. The percentage of zygacine in each sample was determined by HPLC-mass spectrometry (MS) analysis on a weight basis of the crude alkaloid extract.

The MLA used in this study was extracted from Delphinium barbeyi following previously published methods (Pelletier et al., 1981, 1989; Manners et al., 1991); MLA is identical in low larkspur. The purified alkaloids and alkaloid extracts were suspended in PBS solution. The $\mathrm{pH}$ of each solution was reduced with $1 \mathrm{~N} \mathrm{HCl}$ to achieve solubility. Ammonium hydroxide $(28 \%)$ was then added to the solutions to increase the $\mathrm{pH}$ above 6.0. The solutions were stored in sterile injection vials 
at $4^{\circ} \mathrm{C}$ until use. No adverse effects were seen after intravenous (i.v.) injections in mice $(0.05$ to $0.2 \mathrm{~mL})$ of a PBS solution at $\mathrm{pH} 6.0$.

\section{Animals}

Male Swiss Webster mice were purchased from Simonson Laboratories Inc. (Gilroy, CA). Mice were acclimated for 3 to $4 \mathrm{~d}$ with free access to food [Harlan Teklad rodent diet (w) 8604, Harlan Teklad, Madison, WI] and water before beginning experiments.

\section{Median Lethal Dose Determination}

The $\mathrm{LD}_{50}$ of each solution was determined using male Swiss Webster mice weighing $25 \pm 3$ g. For i.v. injections, solutions ranging between 0.05 and $0.2 \mathrm{~mL}$ were injected via the tail vein. For oral administration, solutions ranging between 0.09 and $0.45 \mathrm{~mL}$ were administered via a 20 -gauge, 3.8 -cm oral-gavage needle. Mice were observed for clinical effects and mortality. The $\mathrm{LD}_{50}$ of the solutions were determined using a modified up-and-down method (Bruce, 1987). Using this method for acute toxicity testing, animals are dosed one at a time. If the first animal survives, then the next animal receives a larger dose, whereas if the first animal dies the next animal receives a smaller dose. The dose for each successive animal is increased or decreased depending upon the outcome for the previous animal. This causes the doses to be rapidly adjusted toward the $\mathrm{LD}_{50}$ and then be maintained in the region of the $\mathrm{LD}_{50}$. This method is preferred because fewer animals are required; however, it results in unbalanced numbers in each group. The $\mathrm{LD}_{50}$ values were calculated using SAS Proc Probit in a logistic regression (SAS Inst. Inc., Cary, NC).

\section{Toxicokinetic Analyses}

For toxicokinetic studies, 40 male Swiss Webster mice weighing $21 \pm 1 \mathrm{~g}$ were randomly divided into 8 groups of 5 mice each, to obtain samples at 8 time points after injection $(0,1,2,5,10,15,30$, and $60 \mathrm{~min})$. Mice were dosed via the tail vein with $50 \%$ of the i.v. $\mathrm{LD}_{50}$ dose $(1.0 \mathrm{mg} / \mathrm{kg})$, as determined in the $\mathrm{LD}_{50}$ studies. This dose produced clinical signs but no mortality. Mice were killed by $\mathrm{CO}_{2}$ asphyxiation followed by cervical dislocation. Whole blood $(0.5 \mathrm{~mL})$ was collected by cardiac puncture and frozen at $-20^{\circ} \mathrm{C}$ until analyzed.

\section{Sample Extractions}

Whole blood samples were thawed, vortexed, and then centrifuged at $16,000 \times g$ at room temperature for $5 \mathrm{~min}$. A $200-\mu \mathrm{L}$ aliquot was taken and placed in a 2-mL eppendorf tube. To each sample was added an equal volume of acetonitrile $(200 \mu \mathrm{L})$. Samples were vortexed and centrifuged at $16,000 \times g$ at room temperature for $5 \mathrm{~min}$. A $200-\mu \mathrm{L}$ aliquot was transferred to HPLC autosample vial and samples again centrifuged $2,500 \times g$ at room temperature for $5 \mathrm{~min}$ before analysis. Standards were prepared from a stock solution of purified zygacine $(0.5 \mathrm{mg} / \mathrm{mL}$, chloroform $)$ at $1,000,500,250,125,62.5$, and $31 \mathrm{ng} / \mathrm{mL}$ by serial dilutions using $50 \%$ acetonitrile in water. Samples and standards were analyzed by HPLC-tandem mass spectrometry (MS/MS) using a Thermo Finnigan LCQ Advantage Max MS coupled with a Thermo Finnigan Surveyor autosampler, MS solvent pump, and electrospray ion source (Thermo Finnigan, San Jose, CA). The HPLC column was a Betasil C18 column $(100 \times$ $2.1 \mathrm{~mm}$, Thermo Fisher Scientific Inc., Waltham, MA) with a guard column $(10 \times 2.1 \mathrm{~mm})$ of equivalent phase eluted with a gradient mixture of methanol $/ 20 \mathrm{mM}$ ammonium acetate at a flow rate of $0.300 \mathrm{~mL} / \mathrm{min}$. Solvent gradient: $10 \%$ methanol ( 0 to $2 \mathrm{~min}$ ); 10 to $40 \%$ methanol (2 to $3 \mathrm{~min}$ ); 40 to $80 \%$ methanol (3 to 10 min); isocratic $80 \%$ methanol (10 to $14 \mathrm{~min}$ ). Injection volume was $5 \mu \mathrm{L}$. Zygacine was detected from the reconstructed ion chromatograms $(m / z=518)$ from the $m / z 536$ to $518 \mathrm{MS} / \mathrm{MS}$ transition and calibration and quantitation based on peak area measurements. Based on sample signal-to-noise ratio of 3 and 10, the limit of detection and quantitation were estimated to be 4 and $10 \mathrm{ng} / \mathrm{mL}$, respectively, in the blood. Identification of the zygacine was based on comparison of retention time and MS/MS fragmentation pattern. The interassay CV for this method is approximately $11 \%$.

\section{Analysis and Statistics}

Statistical comparisons of toxicokinetic profiles between 3 or more groups were performed using ANOVA with a posthoc test of significance between individual groups using SigmaStat (SPSS Inc., Richmond, CA). Statistical comparisons of toxicokinetic profiles between 2 groups were performed using a 2-tailed, unpaired Student's $t$-test. The alkaloid concentrations were plotted. Kinetic profiles were analyzed using standard pharmacokinetic software (PK Solutions 2.0 for Noncompartmental Pharmacokinetic Data Analysis, Summit Research Services, Montrose, CO). A curve-stripping procedure was used to determine the basic pharmacokinetic parameters of half-life and rate for the elimination phase from blood of the zygacine concentration curve. The following variables were determined: $t^{1} \mathbf{2}$, $\mathbf{k}_{\text {elim }}, \mathbf{V d}, \mathbf{C l}$, and $\mathbf{A U C}$, where $\mathrm{t}^{1 / 2}$ is the elimination half-life, $\mathrm{k}_{\text {elim }}$ is the elimination rate, $\mathrm{Vd}$ is the volume of distribution, and $\mathrm{Cl}$ is the clearance rate in blood, and AUC is the area under the curve. The trapezoidal method was used to determine the AUC of a concentration vs. time graph.

\section{RESULTS}

Chromatograms (HPLC-MS) of alkaloid extracts from 2 death camas ( $Z$. paniculatus) collections used for this study are shown in Figure 2. Zygacine (reten- 


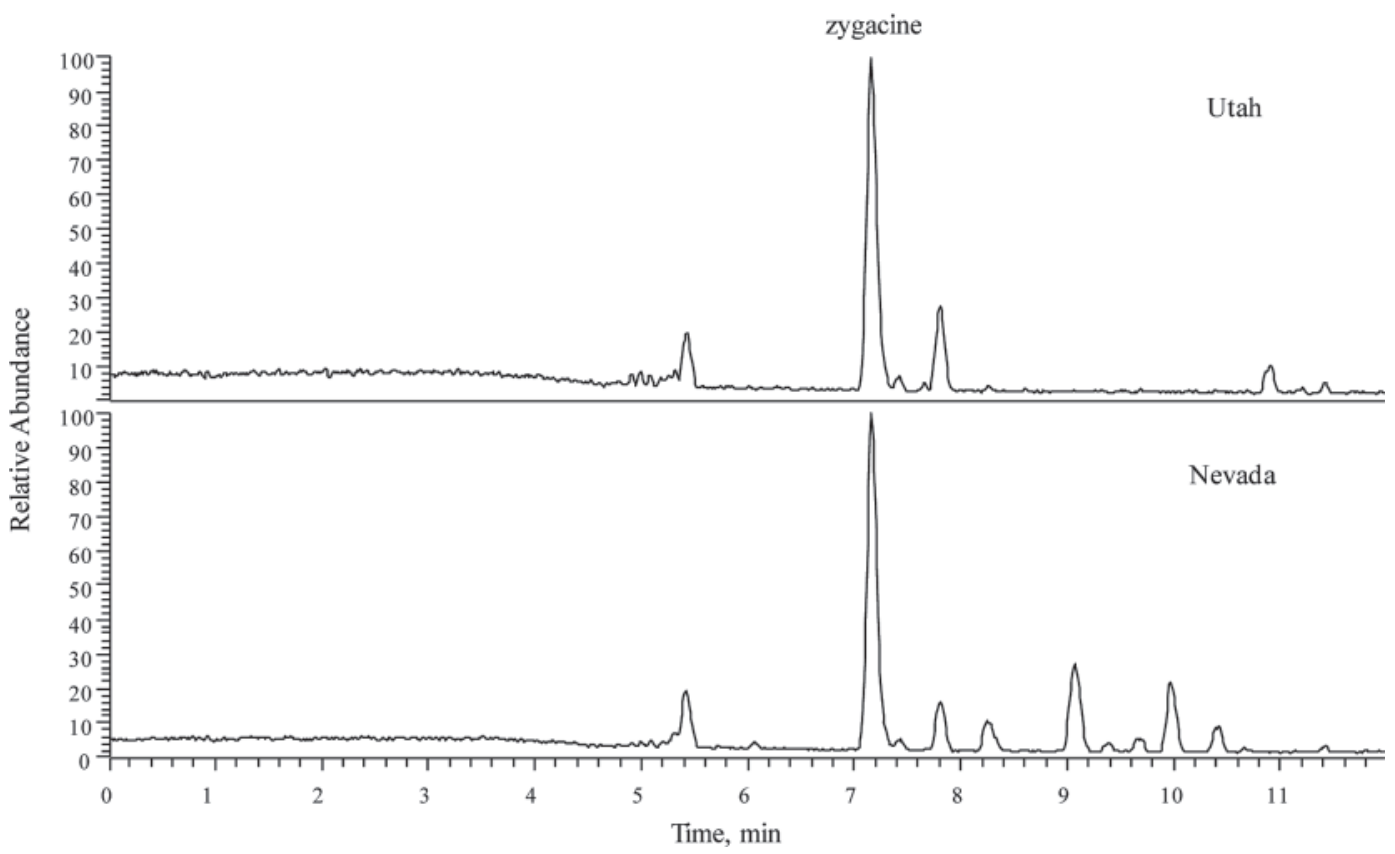

Figure 2. Reconstructed base peak ion chromatograms from HPLC-tandem mass spectrometry (MS/MS) analysis of total alkaloid extracts from 2 Zigadenus paniculatus populations. Identification of zygacine (retention time $=7.2 \mathrm{~min}$ ) was based on comparison of retention time and MS/MS fragmentation pattern with standard. Unidentified peaks are presumed to be other minor alkaloids in the plant based on the isolation procedure for the analyzed extract. The percentage of zygacine in each sample was determined by HPLC-mass spectrometry analysis on a weight basis of the crude alkaloid extract.

tion time $=7.2 \mathrm{~min})$ was the major alkaloid in both extracts. In the Utah collection, zygacine was $58 \%$ of the total crude alkaloid residue. For the Nevada collection, zygacine was $41 \%$ of the total crude alkaloids.

The acute toxicity of zygacine was compared with the total alkaloid extracts from the 2 death camas collections (Figure 3 and Table 1). The i.v. $\mathrm{LD}_{50}$ of zygacine was $2.0 \pm 0.2 \mathrm{mg} / \mathrm{kg}$, whereas the i.v. $\mathrm{LD}_{50}$ of the total alkaloid extracts were $2.8 \pm 0.8$ and $2.2 \pm 0.3 \mathrm{mg} /$ $\mathrm{kg}$ for the Utah and Nevada collections, respectively. In addition to determining the $\mathrm{LD}_{50}$ of zygacine administered i.v., we also determined the $\mathrm{LD}_{50}$ of zygacine administered orally to mice (Figure 4 and Table 1 ). The oral $\mathrm{LD}_{50}$ of zygacine in mice was $132 \pm 21 \mathrm{mg} / \mathrm{kg}$.

Clinical signs of poisoning in mice treated i.v. with a lethal dose of zygacine or total alkaloid extract from death camas were as follows: within seconds of injection, mice were reluctant to move. Within $1 \mathrm{~min}$, mice developed chewing movements, excessive facial grooming, and increased aggression to neighboring animals. As these symptoms became more severe, poisoned mice developed muscle tremors and spastic involuntary muscular contractions seen as marked extension of the head and neck as well as tail flicking and signaling. These involuntary tremors became more severe until the mice were fatigued and could not move voluntarily. Lethally poisoned mice struggled for breath, which was seen as spasmodic jumps and shaking. These animals quickly became cyanotic and died. Typically, lethally poisoned animals died within 2 min of treatment. Animals that did not die recovered within $20 \mathrm{~min}$; however, the mice remained hypersensitive to any stimulation for 1 to $2 \mathrm{~h}$ after treatment. The clinical signs of poisoning in mice treated orally were very similar to those observed in the i.v. dosed mice, except for a delay (20 to $30 \mathrm{~min}$ ) in the onset, and they also remained hypersensitive for a longer duration (2 to $4 \mathrm{~h}$ ).

Five mice were dosed i.v. with zygacine at $1.0 \mathrm{mg} /$ $\mathrm{kg}$ for each time point of sample collection. Blood was collected from the mice, and zygacine was extracted from whole blood and analyzed by HPLC-MS/MS (Figure 5). The elimination kinetic profile of zygacine from

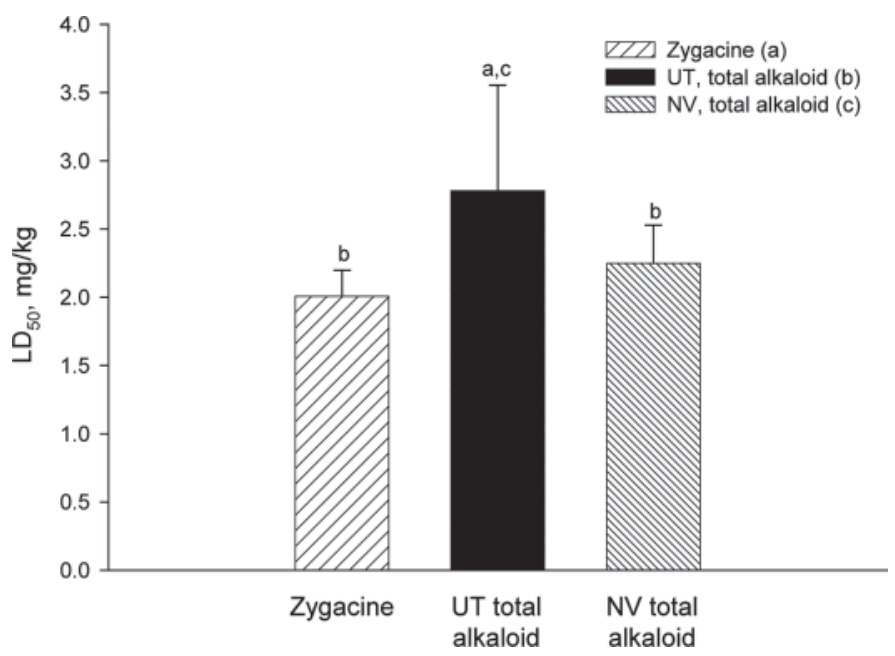

Figure 3. Comparison of the acute toxicity of zygacine vs. a total alkaloid extract from a Utah (UT) and a Nevada (NV) death camas population. The data represent the $\mathrm{LD}_{50}$ of zygacine and total alkaloid extracts from 2 different collections of death camas (Zigadenus paniculatus). Results represent the mean $\pm \mathrm{SD}$ of 24 to 31 mice per group. Letters $(\mathrm{a}-\mathrm{c})$ above bars designate groups for which there is a difference, $P<0.05$. 
Table 1. Median lethal dose, BW, and injection volume for 2 death camas (Zigadenus paniculatus) extracts (total alkaloids) from Utah and Nevada, purified zygacine (intravenous and oral routes), purified methyllycaconitine (MLA), and a combination of zygacine plus MLA ${ }^{1}$

\begin{tabular}{lcccc}
\hline \hline Compound & $\begin{array}{c}\text { Sample } \\
\text { size }\end{array}$ & $\mathrm{LD}_{50}{ }^{2} \mathrm{mg} / \mathrm{kg}$ & $\mathrm{BW},{ }^{3} \mathrm{~g}$ & $\begin{array}{c}\text { Injection } \\
\text { volume }{ }^{4} \mathrm{~mL}\end{array}$ \\
\hline Alkaloid extract, Utah & 34 & $2.8 \pm 0.8$ & $22.9 \pm 1.6$ & $0.16 \pm 0.04$ \\
Alkaloid extract, Nevada & 24 & $2.2 \pm 0.3$ & $29.8 \pm 2.0$ & $0.16 \pm 0.04$ \\
Zygacine & 31 & $2.0 \pm 0.2$ & $23.9 \pm 1.9$ & $0.13 \pm 0.05$ \\
Zygacine, oral & 38 & $132 \pm 21$ & $26.4 \pm 3.2$ & $0.27 \pm 0.10$ \\
MLA & 28 & $4.6 \pm 0.5$ & $23.0 \pm 1.2$ & $0.14 \pm 0.02$ \\
Zygacine + MLA (1:1) & 39 & $2.9 \pm 0.7$ & $23.5 \pm 1.4$ & $0.09 \pm 0.02$ \\
\hline
\end{tabular}

${ }^{1}$ Material was administered to mice intravenously unless otherwise indicated.

${ }^{2}$ Results represent the mean $\pm \mathrm{SD}$ of the $\mathrm{LD}_{50}$.

${ }^{3}$ Results represent the mean \pm SD of the animal BW.

${ }^{4}$ Results represent the mean $\pm \mathrm{SD}$ of the injection volume.

whole blood was characterized (Figure 6). The rate of elimination of zygacine from whole blood was determined to be $0.06 \pm 0.01 / \mathrm{min}$, which corresponded to a $\mathrm{t}^{1 / 2}$ of $13.0 \pm 2.7 \mathrm{~min}$. Consequently, in the mouse $99 \%$ of the zygacine is eliminated from blood in approximately $91 \mathrm{~min}$. The AUC was calculated to be $5.6 \pm 1.0$ $\mu \mathrm{g} / \mathrm{mL} \times \min$. The volume of distribution for zygacine was $74.8 \pm 20.6 \mathrm{~mL}$, and the clearance rate was $4.0 \pm$ $0.6 \mathrm{~mL} / \mathrm{min}$.

A main objective of this study was to determine if coadministration of a toxic larkspur alkaloid would exacerbate the toxicity of zygacine. The $\mathrm{LD}_{50}$ values of MLA and zygacine were $4.6 \pm 0.5$ and $2.0 \pm 0.2 \mathrm{mg} /$ $\mathrm{kg}$, respectively (Figure 7 and Table 1). In comparison, the $\mathrm{LD}_{50}$ of a $1: 1$ mixture of MLA to zygacine was 2.9 $\pm 0.7 \mathrm{mg} / \mathrm{kg}$. The $\mathrm{LD}_{50}$ value for the mixture is almost halfway between the $\mathrm{LD}_{50}$ values for the individual compounds, suggesting that both alkaloids contribute to the toxicity. Also, the mice treated with this mixture showed clinical signs very similar to those of mice treated with zygacine alone, including time to death. Similar results were observed when the toxicity of a 1:1 mixture of a death camas total alkaloid extract and a low larkspur total alkaloid extract was compared with the toxicities of the individual total alkaloid extracts (data not shown).

\section{DISCUSSION}

In most rangeland settings, there are multiple poisonous plants growing in the same area (Kingsbury, 1964; Burrows and Tyrl, 2001). Consequently, animals are exposed to numerous poisons and not just a single toxin. For many of the poisonous plants, basic toxicological information is available such as the $\mathrm{LD}_{50}$, the mechanism of action, and the clinical signs associated with their toxicoses (Burrows and Tyrl, 2001; Burrows et al., 2004; Panter et al., 2007). However, very rarely is there information available on the effects of animals consuming combinations of these poisonous plants. Thus, questions remain as to whether consumption of multiple poisonous plants by an animal could have an additive, synergistic, or antagonistic effect. There is potential that the toxicosis elicited by one toxin could potentiate the toxicity of another toxin such that a sublethal dose of each toxin, when combined, could produce a lethal result (Davis and Hatoum, 1980; Huff et al., 1988; Welch et al., 2008; Hellmann et al., 2010).

One of the objectives of this study was to determine if the coadministration of MLA, the major toxic alkaloid in low larkspur (Bai et al., 1994; Gardner and Pfister, 2009), would exacerbate the toxicity of zygacine, the major toxic alkaloid in death camas. Death camas and low larkspur are commonly found in the same geographical locations and growing at the same time (Burrows and Tyrl, 2001). Thus, foraging animals could potentially consume both plants. In fact, we have repeatedly seen evidence that livestock have consumed both plants (K. D. Welch, unpublished observations). Additionally, both zygacine and MLA have been identified in the blood and gastrointestinal contents from poisoned animals (D. R. Gardner, personal observations). Much information is known about the toxicity

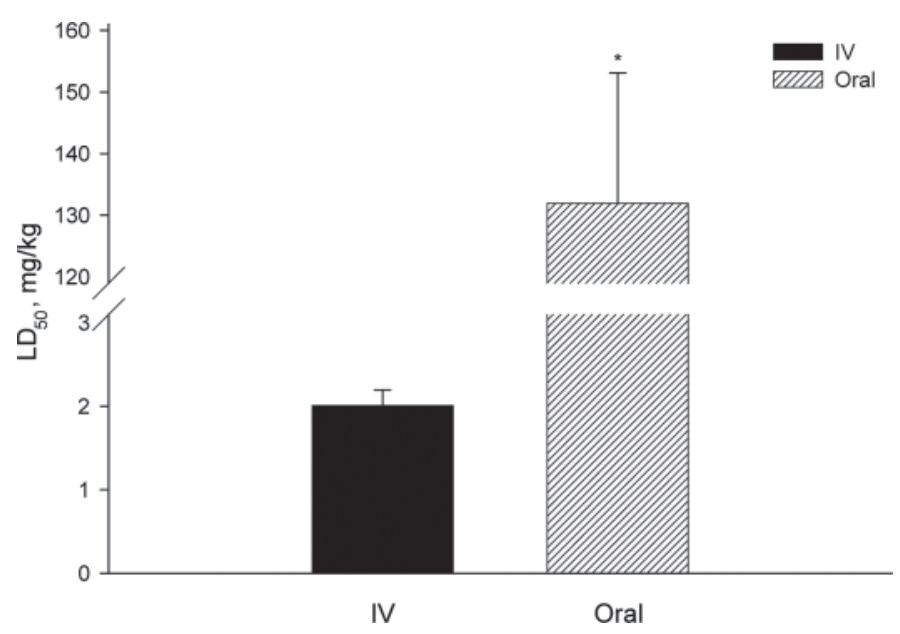

Figure 4. Comparison of the intravenous $\mathrm{LD}_{50}$ vs. the oral $\mathrm{LD}_{50}$ of zygacine. The data represent the $\mathrm{LD}_{50}$ of zygacine dosed intravenously (IV) and orally. Results represent the mean \pm SD of 31 to 38 mice per group; ${ }^{*} P<0.05$ as compared with the IV-dosed group. 

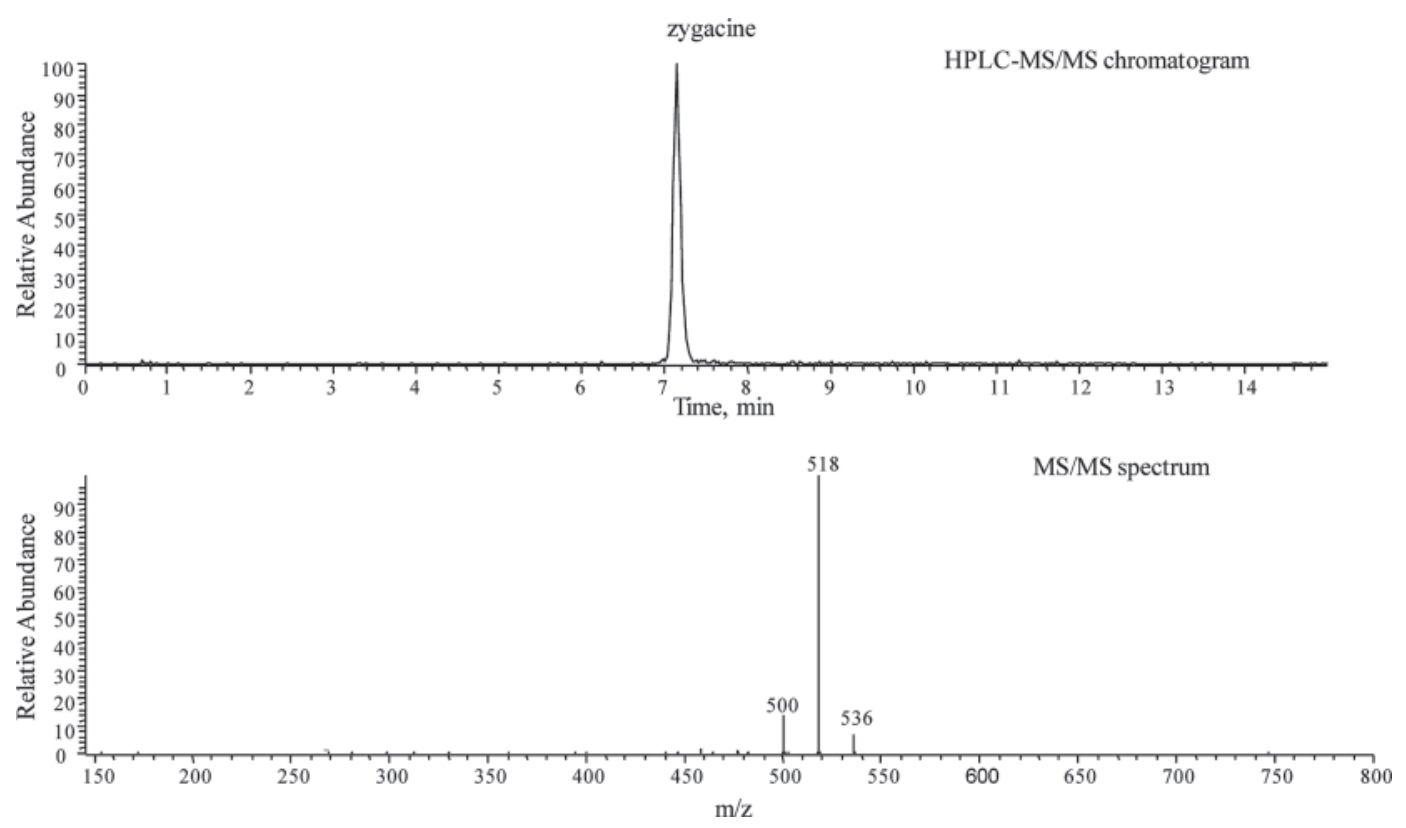

Figure 5. Reconstructed ion chromatogram $(m / z=518)$ from HPLC-tandem mass spectrometry (MS/MS) analysis of whole blood showing the detection of zygacine (upper panel) and the corresponding MS/MS spectrum of zygacine (fragmentation of parent ion $m / z 536$ ) below.

of larkspur (Pfister et al., 1999; Green et al., 2009). The $\mathrm{LD}_{50}$ for i.v. route of administration in mice is approximately $4.5 \mathrm{mg} / \mathrm{kg}$ (Pfister et al., 1999; Panter et al., 2002; Welch et al., 2008, 2009). The mechanism of action is via the competitive inhibition of nicotinic acetylcholine receptors, causing muscle weakness and death due to respiratory failure (Benn and Jacyno, 1983; Dobelis et al., 1999). Less is known about the toxicity of death camas (Panter et al., 1987; Burrows et al., 2004; Panter et al., 2007). The toxic alkaloids in death camas are steroidal alkaloids of the same class as those in Veratrum species (Kupchan, 1959; Burrows and Tyrl, 2001), which are suggested to alter sodium transport in the cardiac nerves (Burrows et al., 2004).

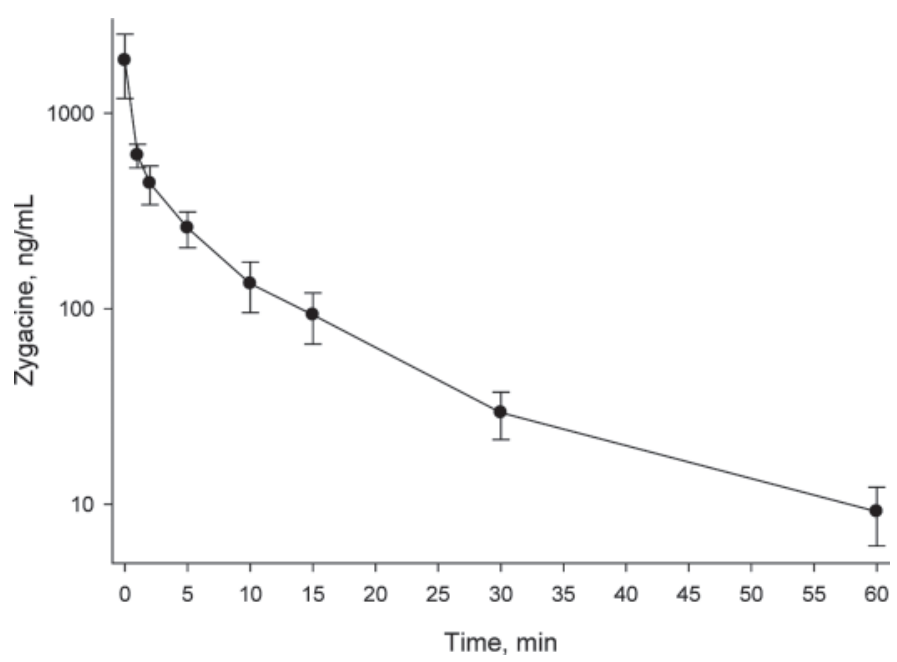

Figure 6. Kinetic profile of zygacine in whole blood. Data represent the whole blood concentration of zygacine from mice dosed intravenously with $1.0 \mathrm{mg} / \mathrm{kg}$ of zygacine. Results represent the mean $\pm \mathrm{SD}$ of the concentration of zygacine in whole blood for 5 mice at each time point.
The clinical signs of animals poisoned by death camas include ataxia, muscular weakness, trembling, incoordination, discharge of frothy saliva from the mouth and nose, vomition, dyspnea, collapse, and death (Panter et al., 1987). Based on the clinical signs observed, the toxic alkaloids in death camas likely affect more than just the sodium channels in the cardiac nerves. However, because the toxins from both plants appear to be neurotoxins, there is a possibility that the inhibition of nicotinic acetylcholine receptors by larkspur alkaloids could exacerbate the toxicosis caused by death camas alkaloids.

Before performing these types of experiments in larger livestock species, we first used a rodent mod-

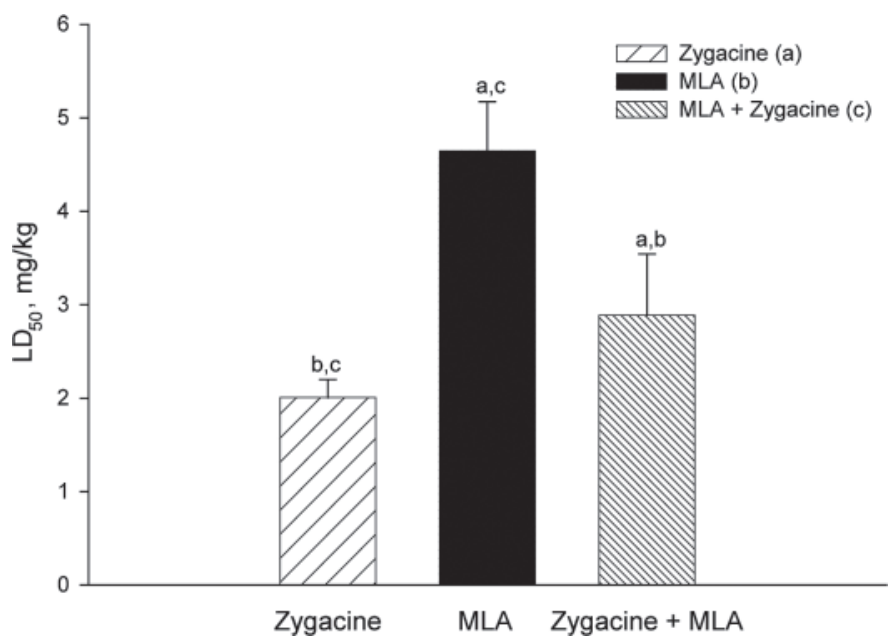

Figure 7. Comparison of the acute toxicity of zygacine, methyllycaconitine (MLA), as well as a 1:1 mixture of zygacine and MLA. The data represent the $\mathrm{LD}_{50}$ of zygacine, MLA, and a 1:1 mixture of zygacine and MLA. Results represent the mean \pm SD of 28 to 39 mice per group. Letters $(\mathrm{a}-\mathrm{c})$ above bars designate groups for which there is a difference, $P<0.05$. 
el. We were unable to find a published $\mathrm{LD}_{50}$ value for death camas alkaloids, especially zygacine. Therefore, we characterized the acute toxicity of a death camas extract from $Z$. paniculatus, or foothill death camas, and zygacine, the major alkaloid in $Z$. paniculatus. The $\mathrm{LD}_{50}$ for zygacine $(2.0 \mathrm{mg} / \mathrm{kg})$ was different than the alkaloid extract from the Utah collection $(2.8 \mathrm{mg} / \mathrm{kg})$ but not the alkaloid extract from the Nevada collection $(2.2 \mathrm{mg} / \mathrm{kg})$. There was also a difference between the $\mathrm{LD}_{50}$ of the alkaloid extract from the Utah collection and the alkaloid extract from the Nevada collection. Not all of the alkaloids in death camas have been indentified, nor have their toxicities been determined. The alkaloid extract from the Utah collection contained a greater percentage of zygacine than the alkaloid extract from the Nevada collection, and yet the alkaloid extract from the Nevada collection was more toxic. Additionally, the alkaloid extract from the Utah collection was $58 \%$ zygacine, yet the $\mathrm{LD}_{50}$ was only 1.4 times that of zygacine alone. Both of these observations are highly suggestive that other components of the extracts also contributed to the toxicity. Consequently, the results from this study suggest that zygacine is the major alkaloid in Z. paniculatus and that additional alkaloids in death camas contribute to its toxicity. Further studies are needed to identify and characterize the other toxic alkaloids in death camas.

Determination of an $\mathrm{LD}_{50}$ value for a compound administered i.v. is valuable because it provides basic information regarding the toxicity of the parent compound without conflicting factors such as the rate of absorption or potential metabolic changes that can occur before the compound reaches general circulation (Klaassen, 2001; Eaton and Gilbert, 2008). However, i.v. administration is not a real-world scenario for toxins from a poisonous plant. Therefore, we also determined the $\mathrm{LD}_{50}$ value for zygacine administered orally. The $\mathrm{LD}_{50}$ value for orally administered zygacine was approximately $132 \mathrm{mg} / \mathrm{kg}$. This is over 60 times less toxic than i.v. route. It is common for the toxicity of a compound to be less toxic when administered orally vs. i.v. (Lehmann-McKeeman, 2008). There are several potential explanations for the difference, with the primary reason being a reduced rate, or overall amount, of absorption from the gastrointestinal tract (Shargel and $\mathrm{Yu}, 1993)$. The rate at which a compound is absorbed will influence the toxicity of a compound (LehmannMcKeeman, 2008; Shen, 2008). Conversely, with an i.v. administration the entire dose is immediately bioavailable and thus potentially more toxic, if the parent compound is the active toxin (Shargel and Yu, 1993). Similarly, when a compound is administered orally, much of the dosed compound can be metabolized to a less toxic compound en route to general circulation, especially in the liver (Eaton and Gilbert, 2008), rumen microflora (Weimer, 1998), and rumen wall (Watkins et al., 1987; Smith, 1992).

In addition to knowing the $\mathrm{LD}_{50}$ value for zygacine, it is also valuable to know the rate at which zygacine is eliminated from the body, as well as the AUC. We have presumed that elimination from the blood results in elimination from the body and not redistribution within tissues. The kinetic variable AUC provides a general indication as to the bioavailability of a compound, summarily depicting the absorption, distribution, and elimination of the compound (Shargel and $\mathrm{Yu}, 1993)$. The rate of elimination is valuable in both i.v. and orally dosed animals because it dictates how long the toxin will remain in the body (Shargel and Yu, 1993; Shen, 2008). In this study, we found the AUC for zygacine to be approximately $5,550 \mathrm{ng} \cdot \mathrm{mL}^{-1} \times \min$, and the $t^{1} 1 / 2$ for zygacine was $0.06 / \mathrm{min}$, which indicates that the $\mathrm{t}^{1 / 2} \mathrm{f}$ from blood was approximately $13 \mathrm{~min}$. We calculated the Vd to be approximately $75 \mathrm{~mL}$, which indicates that zygacine is widely distributed to the peripheral tissues. However, the clearance rate of $4 \mathrm{~mL} /$ min may indicate that zygacine is either rapidly cleared from the blood or is rapidly metabolized. These kinetic variables are useful in evaluating relative risk and to enhance current management recommendations for animals grazing in death camas-infested rangelands.

A t $1 / 2$ of 13 min indicates that 91 min after exposure over $99.2 \%$ of the zygacine is eliminated from the blood. However, we observed that mice dosed with zygacine in this study remained hypersensitive beyond 91 min. There are several possible explanations for this discrepancy. One explanation is that the toxic alkaloids in death camas bind to a receptor such that residual amounts of alkaloid, below the limit of detection in blood, would maintain the mice in a state of hypersensitivity. Another explanation is that the active compound that binds to the receptor is a metabolite and consequently not accounted for in the kinetic analyses of the parent compound.

The results from this study indicate that both MLA and zygacine are very toxic. The $\mathrm{LD}_{50}$ value for a $1: 1$ mixture of MLA and zygacine $(2.9 \mathrm{mg} / \mathrm{kg})$ was different from the $\mathrm{LD}_{50}$ value of zygacine alone and MLA alone. The i.v. $\mathrm{LD}_{50}$ value of the mixture is almost halfway between the individual values of each compound. However, in essence, the $\mathrm{LD}_{50}$ value for the mixture corresponds to a value of $1.45 \mathrm{mg} / \mathrm{kg}$ for each alkaloid, which is significantly less than the $\mathrm{LD}_{50}$ for each individual compound. Consequently, these results suggest that the toxicity is additive when combining these 2 toxins, at least for an acute i.v. toxicity study in mice. Perhaps in a ruminant animal that is dosed orally, a different interaction between the 2 compounds could occur, including a synergistic interaction. Oral dosing in a ruminant animal to compare individual and combined effects of death camas and larkspur needs to be performed before any management recommendations can be made concerning the risk for animals grazing on rangelands that contain both poisonous plants.

In summary, the results from this study demonstrate that zygacine is a very toxic compound with an i.v. $\mathrm{LD}_{50}$ value of $2 \mathrm{mg} / \mathrm{kg}$ in mice. We also demonstrated that zygacine is the major alkaloid in $Z$. paniculatus 
and that zygacine accounts for the majority of the toxicity of a total alkaloid extract from death camas. In addition, we report the $t^{1 / 2}$ of zygacine in mice to be approximately $13 \mathrm{~min}$. Finally, the coadministration of death camas and low larkspur alkaloids has an additive effect, resulting in enhanced toxicity. The results from this study provide an increased knowledge and understanding regarding the acute toxicity of death camas. This information will be useful in further developing livestock management recommendations for ranchers and in designing additional experiments to study the toxicity of death camas in livestock species.

\section{LITERATURE CITED}

Bai, Y., F. Sun, M. Benn, and W. Majak. 1994. Diterpenoid and norditerpenoid alkaloids from Delphinium nuttallianum. Phytochemistry $37: 1717-1724$.

Benn, M. H., and J. M. Jacyno. 1983. The toxicology and pharmacology of diterpenoid alkaloids. Pages 153-210 in Alkaloids: Chemical and Biological Perspective. S. W. Pelletier, ed. John Wiley and Sons, New York, NY.

Bruce, R. D. 1987. A confirmatory study of the up-and-down method for acute oral toxicity testing. Fundam. Appl. Toxicol. 8:97-100.

Burrows, G. E., and R. J. Tyrl. 2001. Toxic Plants of North America. Iowa State Univ. Press, Ames.

Burrows, G. E., R. J. Tyrl, A. P. Knight, C. Means, P. A. Talcott, W. Hare, J. A. Pickrell, F. Oehme, K. H. Plumlee, G. L. Meerdink, R. L. Fredrickson, G. O. Bordson, K. E. Panter, B. L. Stegelmeier, S. W. Casteel, S. A. Mannala, S. S. Nicholson, P. A. Volmer, F. D. Galey, J. C. Albretsen, B. Puschner, J. Allen, J. O. Hall, and V. Merola. 2004. Plants. Pages 337-442 in Clinical Veterinary Toxicology. K. H. Plumlee, ed. Mosby, St. Louis, MO.

Collet, S., D. Grotelueschen, R. Smith, and R. Wilson. 1996. Deaths of 23 adult cows attributed to intoxication by the alkaloids of Zigadenus venosus (meadow death camas). Agric. Practice $17: 5-9$.

Davis, W. M., and N. S. Hatoum. 1980. Synergism of the toxicity of physostigmine and neostigmine by lithium or by a reserpine-like agent (Ro4-1284). Toxicology 17:1-7.

Dobelis, P., J. E. Madl, J. A. Pfister, G. D. Manners, and J. P. Walrond. 1999. Effects of Delphinium alkaloids on neuromuscular transmission. J. Pharmacol. Exp. Ther. 291:538-546.

Eaton, D. L., and S. G. Gilbert. 2008. Principles of toxicology. Pages 11-43 in Casarett \& Doull's Toxicology: The Basic Science of Poisons. C. D. Klaassen, ed. McGraw-Hill Medical, New York, NY.

Gardner, D. R., and J. A. Pfister. 2009. HPLC-MS analysis of toxic norditerpenoid alkaloids: Refinement of toxicity assessment of low larkspurs (Delphinium spp.). Phytochem. Anal. 20:104113.

Gilbertson, T. J. 1973. Zygacine and zygadenine: The major alkaloids from Zygadenus gramineus. Phytochemistry 12:2079-2080.

Green, B. T., D. R. Gardner, J. A. Pfister, and D. Cook. 2009. Larkspur poison weed: 100 years of Delphinium research. Rangelands $31: 22-27$.

Hellmann, J. K., S. Munter, M. Wink, and F. Frischknecht. 2010. Synergistic and additive effects of epigallocatechin gallate and digitonin on Plasmodium sporozoite survival and motility. PLoS ONE 5:e8682.

Huff, W. E., R. B. Harvey, L. F. Kubena, and G. E. Rottinghaus. 1988. Toxic synergism between aflatoxin and T-2 toxin in broiler chickens. Poult. Sci. 67:1418-1423.

Kingsbury, J. M. 1964. Poisonous Plants of the United States and Canada. Prentice-Hall Inc., Englewood Cliffs, NJ.
Klaassen, C. D. 2001. Principles of toxicology and treatment of poisoning. Pages $67-80$ in Goodman \& Gilman's The Pharmacological Basis of Therapeutics. J. G. Hardman, L. E. Limbird, and A. G. Gilman, ed. McGraw-Hill, New York, NY.

Knight, A. P., and R. G. Walter. 2001. A Guide to Plant Poisoning of Animals in North America. Teton NewMedia, Jackson Hole, WY.

Kupchan, S. M. 1959. Veratrum alkaloids. XXX. The structure and configuration of zygadenine. J. Am. Chem. Soc. 81:19251928.

Lehmann-McKeeman, L. D. 2008. Absorption, distribution, and excretion of toxicants. Pages 131-160 in Casarett \& Doull's Toxicology: The Basic Science of Poisons. C. D. Klaassen, ed. McGraw-Hill Medical, New York, NY.

Majak, W., R. E. McDiarmid, W. Cristofoli, F. Sun, and M. Benn. 1992. Content of zygacine in Zygadenus venenosus at different stages of growth. Phytochemistry 31:3417-3418.

Manners, G. D., J. A. Pfister, M. H. Ralphs, K. E. Panter, and J. D. Olsen. 1991. Larkspur chemistry: Toxic alkaloids in tall larkspurs. J. Range Manage. 45:63-67.

Morris, M. D. 1944. Nuttall death camas poisoning in horses. Vet. Med. 39:462.

Panter, K. E., D. R. Gardner, S. T. Lee, J. A. Pfister, M. H. Ralphs, B. L. Stegelmeier, and L. F. James. 2007. Important poisonous plants of the United States. Pages 825-872 in Veterinary Toxicology: Basic and Clinical Principles. R. C. Gupta, ed. Academic Press, New York, NY.

Panter, K. E., G. D. Manners, B. L. Stegelmeier, S. Lee, D. R. Gardner, M. H. Ralphs, J. A. Pfister, and L. F. James. 2002. Larkspur poisoning: Toxicology and alkaloid structure-activity relationships. Biochem. Syst. Ecol. 30:113-128.

Panter, K. E., M. H. Ralphs, R. A. Smart, and B. Duelke. 1987. Death camas poisoning in sheep: A case report. Vet. Hum. Toxicol. 29:45-48.

Pelletier, S. W., O. D. Daily Jr., N. V. Moody, and J. D. Olsen. 1981. Isolation and structure elucidation of alkaloids of Delphinium glaucescens Ryb. J. Org. Chem. 46:3284-3293.

Pelletier, S. W., P. Kulanthaivel, and J. D. Olsen. 1989. Alkaloids of Delphinium barbeyi. Phytochemistry 28:1521-1525.

Pfister, J. A., D. R. Gardner, K. E. Panter, G. D. Manners, M. H. Ralphs, B. L. Stegelmeier, and T. K. Schoch. 1999. Larkspur (Delphinium spp.) poisoning in livestock. J. Nat. Toxins 8:81-94.

Shargel, L., and A. B. C. Yu. 1993. Applied Biopharmaceutics and Pharmacokinetics. 3rd ed. Appleton \& Lange, Stamford, CT.

Shen, D. D. 2008. Toxicokinetics. Pages 305-325 in Casarett \& Doull's Toxicology: The Basic Science of Poisons. C. D. Klaassen, ed. McGraw-Hill Medical, New York, NY.

Smith, G. S. 1992. Toxification and detoxification of plant compounds by ruminants: An overview. J. Range Manage. 45:2530 .

Smith, R. A., and D. Lewis. 1991. Death camas poisoning in cattle. Vet. Hum. Toxicol. 33:615-616.

Watkins, J. B. III, G. S. Smith, and D. M. Hallford. 1987. Characterization of xenobiotic biotransformation in hepatic, renal and gut tissues of cattle and sheep. J. Anim. Sci. 65:186-195.

Weimer, P. J. 1998. Manipulating ruminal fermentation: A microbial ecological perspective. J. Anim. Sci. 76:3114-3122.

Welch, K. D., B. T. Green, K. E. Panter, D. R. Gardner, J. A. Pfister, D. Cook, and B. L. Stegelmeier. 2009. Investigation of the susceptibility of various strains of mice to methyllycaconitine toxicosis. J. Anim. Sci. 87:1558-1564.

Welch, K. D., K. E. Panter, D. R. Gardner, B. T. Green, J. A. Pfister, D. Cook, and B. L. Stegelmeier. 2008. The effect of 7,8-methylenedioxylycoctonine-type diterpenoid alkaloids on the toxicity of methyllycaconitine in mice. J. Anim. Sci. $86: 2761-2770$. 
References

This article cites 25 articles, 5 of which you can access for free at: http://jas.fass.org/cgi/content/full/89/5/1650\#BIBL 